\title{
Associations of udder-health indicators with cow factors and with intramammary infection in dairy cows
}

\author{
A.-K. Nyman, ${ }^{* 1}$ K. Persson Waller, ${ }^{*} †$ T. W. Bennedsgaard, $\ddagger$ T. Larsen, $\ddagger$ and U. Emanuelson† \\ *Department of Animal Health and Antimicrobial Strategies, National Veterinary Institute (SVA), SE-751 89 Uppsala, Sweden \\ †Department of Clinical Sciences, Swedish University of Agricultural Sciences, PO Box 7054, SE-750 07 Uppsala, Sweden \\ łDepartment of Animal Science, Faculty of Science and Technology, Aarhus University, Blichers Allé 20, Tjele, Denmark
}

\section{ABSTRACT}

The objective of this study was to investigate if and how cow factors and intramammary infection (IMI) are associated with 4 different udder-health indicators in dairy cows as a first step in investigating whether the diagnostic performance of these indicators can be improved. The investigated indicators were somatic cell count (SCC), lactate dehydrogenase (LDH), N-acetyl- $\beta$ D-glucosaminidase (NAGase), and alkaline phosphatase (AP) measured in milk. In this cross-sectional study, approximately 1,000 cows from 25 dairy herds were sampled for bacteriology (quarter milk samples) during 3 consecutive days: the day before test milking, at the day of test milking, and at the day after test milking. The whole-udder test milking sample was analyzed for milk composition, SCC, LDH, NAGase, and AP. Cow data (parity, breed, milk yield, percentage of milk fat and protein, milk urea concentration, and days in milk from the sampled test milking) were collected from the Swedish milk-recording scheme. Of the sampled cows 485 were considered IMI negative and were used in multivariable mixed-effect linear regression models to investigate associations between cow factors and the udder-health indicators. A second modeling including all cows, both IMI negative and IMI positive (256 cows), was also performed. The results showed that all udder-health indicators were affected by cow factors but that different cow factors were associated with different indicators. Intramammary-infection status was significantly associated with all udder-health indicators except AP. Parity and milk urea concentration were the only cow factors associated with all indicators in all models. The significant cow factors explained $23 \%$ of the variation in SCC and $>30 \%$ of the variation in LDH, NAGase, and AP in IMI-negative cows, showing that LDH, NAGase, and AP are more affected than SCC by cow factors. The IMI status explained $23 \%$

Received December 30, 2013.

Accepted May 30, 2014.

${ }^{1}$ Corresponding author: ann.nyman@sva.se of the variation in SCC in the model with all cows but only $7 \%$ of the variation in $\mathrm{LDH}$ and $2 \%$ of the variation in NAGase, indicating that $\mathrm{SCC}$ has the best potential as a diagnostic tool in finding cows with IMI. However, further studies are needed to investigate whether the diagnostic properties of these udder-health indicators will improve with adjustment according to their associations with different cow factors when used as a diagnostic tool for finding cows with IMI.

Key words: somatic cell count, lactate dehydrogenase, $\mathrm{N}$-acetyl- $\beta$-D-glucosaminidase, alkaline phosphatase

\section{INTRODUCTION}

Mastitis in dairy cows causes economic losses for the farmers (Halasa et al., 2007) because of reduction in milk production (Hagnestam et al., 2007; Dürr et al., 2008) and milk quality (Kitchen, 1981; Sandholm et al., 1995), costs of veterinary services, extra labor, and so on, and it affects the welfare of the cow. Cases of clinical mastitis are generally easy to detect because the signs are visible, and the affected cow can be treated and separated from healthy cows, eliminating a risk of transition of udder pathogens to healthy cows. Cows with subclinical mastitis, however, have no visible signs of mastitis and are therefore a hidden threat to healthy cows in the herd. In Sweden the most common udder pathogen found in cases of subclinical mastitis is Staphylococcus aureus (Persson et al., 2011), a pathogen considered to be very contagious; hence, it is very important to identify infected cows to reduce the spread of bacteria in the herd. This reasoning is also valid for other contagious udder infections.

Today the best method to identify cows with IMI is to take milk samples for bacterial culturing or PCR assay. However, to sample all udder quarters of all cows in a herd is expensive. Instead, diagnostic tools identifying the inflammatory response are used, most commonly involving analyses of SCC in composite milk samples (from the test milking), because bacterial infections generally lead to increased SCC. Milk samples from high-SCC cows can then be collected and analyzed for 
bacterial content. However, other factors than IMI have been shown to affect the SCC, e.g., parity (Walsh et al., 2007; Reksen et al., 2008), breed (Brolund, 1985; Walsh et al., 2007), DIM (Brolund, 1985; Laevens et al., 1997; Schepers et al., 1997), and milk production (Brolund, 1985; Walsh et al., 2007), which may reduce the specificity ( $\mathbf{S p}$ ) and the negative predictive value of SCC as a diagnostic tool, especially if a low SCC cut-off is used. Hence, to improve the diagnostic abilities of SCC, the test milking composite milk SCC (CMSCC) can be adjusted according to the associations with different cow factors. This adjustment is meant to make it easier to identify cows with an increase in SCC due to IMI, because it would increase both the sensitivity (Se) and Sp of SCC, and to make it easier to compare the CMSCC of cows in a herd. In Sweden, the CMSCC has been adjusted, since the late 1980s, for parity, breed, milk yield ( $\mathrm{kg}$ of milk/d), and DIM, and the adjusted CMSCC of 2 to 3 consecutive test milkings is used in a regression analysis to calculate a probability that the cow has one or more udder quarters with IMI (Brolund, 1990). This tool is called udder-health classes. Udderhealth classes are used by farmers to group cows in "probably infected" and "probably uninfected" and as a tool to select cows for sampling for bacteriology and for dry-cow therapy.

Udder-health indicators other than SCC exist, which also change during inflammation and can be measured in milk. The activity of the enzymes lactate dehydrogenase (LDH), N-acetyl- $\beta$-D-glucosaminidase (NAGase), and alkaline phosphatase (AP) have all been shown to be associated with mastitis or IMI (Bogin and Ziv, 1973; Nielsen et al., 2005; Chagunda et al., 2006; Babaei et al., 2007). These udder-health indicators have not yet been able to replace SCC as the most-used udder-health measurement tool. However, in recent years new and more efficient and economically viable analysis methods of the activity of these enzymes have been developed (Larsen, 2005; Larsen et al., 2010). Some studies have shown that these enzymes also are affected by cow factors, but they do not show to what extent (Berning and Shook, 1992; Chagunda et al., 2006; Piccinini et al., 2007; Wenz et al., 2010).

The need for adjustment of SCC, LDH, and NAGase for the effect of different cow factors has been discussed by others (Mattila et al., 1986; Vecht et al., 1989; Chagunda et al., 2006). However, if adjustments of CMSCC are used, the underlying calculations of the adjustments need to be revised regularly as the cow population changes genetically, and associations found decades ago may not be applicable to the cows of today. Hence, the main aim of the present project was to investigate if and how different cow factors and CMSCC, LDH, NAGase, and AP are associated in IMI- negative cows. Our hypotheses were that CMSCC in IMI-negative cows are affected by cow factors and that LDH, NAGase, and AP activities in IMI-negative cows also are affected by cow factors but to a lower extent than SCC. A model including only IMI-negative cows would more clearly show the systematic effects of the cow factors on each udder-health indicator compared with a model including all cows where IMI status can have a substantial confounding effect with the other explanatory variables. A second aim was to investigate how IMI status was associated with the different udder-health indicators to assess whether some of the indicators have better potential as a diagnostic tool to distinguish cows with and without IMI.

\section{MATERIALS AND METHODS}

\section{Study Design}

This study was designed as a cross-sectional study. The sample size was calculated to obtain a good estimate of the $\mathrm{Se} / \mathrm{Sp}$ of CMSCC when used as a diagnostic tool to predict cows as IMI negative and IMI positive. To obtain a $\mathrm{Se} / \mathrm{Sp}$ of 0.8 with a precision of $10 \%$, a $95 \%$ confidence interval, and a cluster effect of 3 , at least 183 observations would be needed. With an estimated prevalence of IMI of $20 \%$, approximately 1,000 observations would be needed to be able to get the desired Se/Sp. A random sample of herds ( $\mathrm{n}=$ 35 ) with a milking parlor, an annual herd size of 60 to 200 dairy cows, at least $30 \%$ of the cows of each of the 2 main Swedish dairy breeds (Swedish Red, SR, and Swedish Holstein, $\mathbf{S H}$ ), and an estimated bulk milk SCC of 150,000 to 300,000 cells $/ \mathrm{mL}$ were contacted and asked to participate. In total, 25 dairy herds located in the southern half of Sweden were recruited, and to obtain a total of 1,000 sampled cows, 40 cows were sampled in each herd.

\section{Visits}

Each herd was visited twice, 2 to 4 mo apart, during the housing season, i.e., between October 2009 and April 2010. At these visits, a technician from the local livestock association attended one milking occasion (morning or evening) at the day before the routine test milking, at the day of test milking, and at the day after test milking. The main author met all technicians before the study started and informed them about the sampling technique used in the study.

\section{Cow Selection}

Because the aim of the project was to investigate associations between udder-health indicators and cow fac- 
tors, it was important to ensure that sufficient numbers of cows from each herd were of the SR and SH breed, in different parities, and in different DIM intervals at the sampling occasion. Hence, the main author created a list of cows to sample by randomly selecting cows in each herd with different breeds, parities, and DIM based on data from the most recent test milking (obtained from the Swedish official milk-recording scheme) before the visits for the technicians. The intention was to sample 20 cows at each visit, resulting in a total of 40 different cows in each herd.

\section{Sampling}

Milk samples for bacteriological examination were taken by the technician from each udder quarter at all 3 milking occasions, whereas udder composite milk samples for analysis of CMSCC were taken at the day of test milking and handled according to common practice at testing milking. A separate milk sample, for analysis of LDH, NAGase, and AP, was taken from the udder composite milk sample taken at the test milking.

All quarter milk samples were collected just before machine milking. The udder and teats were first cleaned according to normal farm routines at milking and the first 10 to $15 \mathrm{~mL}$ of milk from each udder quarter was discarded. Then, the teat ends were cleaned with alcohol (70\%), and an aseptic milk sample was collected from each udder quarter in sterile test tubes. As transport medium the authors chose to use Mastistrip cassettes [National Veterinary Institute (SVA), Uppsala, Sweden; Nilsson et al., 1990; Nilsson, 1994; Artursson et al., 2010] because they, at the time of the project, were commonly used in Sweden when taking milk samples of cows. To ensure equal amounts of milk on the 4 filter discs of the Mastistrip cassette, the filter discs were dipped in the milk in the test tubes, one for each udder quarter. Thereafter, the Mastistrip cassettes were sent to the National Veterinary Institute, Uppsala, Sweden, for bacteriological analysis.

\section{Milk Analyses}

The test tubes with bronopol-preserved udder composite milk were frozen at $-20^{\circ} \mathrm{C}$ and sent to the faculty of Agricultural Science, Aarhus University, Foulum, Denmark, for analysis of LDH, NAGase, and AP. Enzyme activities were determined by kinetic fluorometric measurements. Lactate dehydrogenase activity was analyzed according to Larsen (2005); NAGase and AP activity were analyzed according to Larsen et al. (2010).

\section{Bacteriological Culturing}

Bacteriological analyses were performed according to accredited routines at SVA. The filter discs of the
Mastistrip were removed on arrival to the laboratory, and each one was placed in $0.5 \mathrm{~mL}$ of RPMI-1640 cell culture medium (SVA) in a test tube. The test tubes were then gently shaken for $10 \mathrm{~min}$ at room temperature and thereafter incubated for $18 \mathrm{~h}$ at $37^{\circ} \mathrm{C}$. After incubation, $50 \mu \mathrm{L}$ of the milk-medium mixture (corresponding to $10 \mu \mathrm{L}$ of milk) was cultured on blood (5\%) agar plates with esculine, which were incubated at $37^{\circ} \mathrm{C}$ for 16 to $24 \mathrm{~h}$ and reevaluated at $48 \mathrm{~h}$. A milk sample was classified as IMI negative if less than $1 \mathrm{cfu}$ of Staphylococcus aureus or Streptococcus agalactiae was isolated. For other bacteria, the presence of less than 3 cfu was needed for IMI-negative classification. Samples were classified as contaminated if 3 or more bacterial types were isolated from one milk sample and growth of a major udder pathogen was not identified.

\section{Cow Data}

Individual data on SCC, milk yield ( $\mathrm{kg}$ of milk/d), percentage of milk fat and milk protein, and milk urea concentration $(\mathrm{mmol} / \mathrm{L})$ from the test milking at sampling as well as data on breed, parity, and day of calving for each cow were obtained from the Swedish official milk-recording scheme.

\section{Definition of IMI Status}

A cow with 12 IMI-negative udder-quarter samples and cows with 11 IMI-negative udder-quarter samples and one sample with sparse ( $<10$ colonies) mixed flora were considered IMI negative. Cows with findings of the same pathogen in the same quarter at 2 out of 3 sampling occasions or a finding of $\geq 10$ colonies of a pathogen in an udder quarter at $\geq 1$ sampling occasion were considered IMI positive.

\section{Statistical Analyses}

Associations between the dependent variables SCC, LDH, NAGase, and AP, and the independent variables breed, parity, DIM, milk yield, percentage of milk fat, percentage of milk protein, concentration of milk urea, and period of sampling (October-November, December-February, and March-April) were analyzed first for IMI-negative cows only and then for both IMInegative and IMI-positive cows (including IMI status as an independent variable) using univariable and multivariable mixed-effect linear regression models. Mixed-effect models were used to take into account that cows within a herd are more similar than cows between herds; hence, the random effect in the mixed models was cow within herd, and an identity covariance structure (equal variances for random effects, all covari- 
Table 1. Bacterial findings from 11,867 quarter milk samples from 976 cows in 25 dairy herds visited during October 2009 to April 2010

\begin{tabular}{|c|c|c|c|c|}
\hline Bacterial findings & Day 1 & Day 2 & Day 3 & Total, no. $(\%)$ \\
\hline Mixed flora & 187 & 172 & 230 & $589(5)$ \\
\hline Staphylococcus aureus & 83 & 88 & 92 & $263(2)$ \\
\hline Streptococcus uberis & 33 & 36 & 42 & $111(0.9)$ \\
\hline $\mathrm{CNS}$ & 141 & 146 & 155 & $442(4)$ \\
\hline Enterococcus spp. & 16 & 12 & 7 & $35(0.3)$ \\
\hline Pasteurella spp. & 1 & 2 & 1 & $4(<0.1)$ \\
\hline Streptococcus agalactiae & 6 & 3 & 4 & $13(<0.1)$ \\
\hline Coagulase-positive Staphylococcus spp. (not Staph. aureus) & 1 & 2 & 1 & $4(<0.1)$ \\
\hline Streptococcus spp. & 1 & 1 & 4 & $6(<0.1)$ \\
\hline More than one dominating finding & 0 & 2 & 1 & $3(<0.1)$ \\
\hline Total & 3,955 & 3,956 & 3,956 & 11,867 \\
\hline
\end{tabular}

ances are zero) was used. The continuous independent variables were assessed if they were linearly related to the outcome by visual examination (using the "lowess" command in Stata), and if not, they were either categorized using percentiles as cut-offs or transformed using the natural logarithm, Box-Cox transformation, or fractional polynomial regression. A manual stepwise backward variable selection procedure was used in the multivariable analyses where the initial model included all independent variables as main effects. Collinearity between the independent variables was assessed pairwise by Spearman rank correlations. When proof of collinearity $(\mathrm{r} \geq 0.70)$ existed, the variable with lowest $P$-value in the univariable analysis was selected. Cows with missing data in either a dependent or independent variable were not included in the models. All plausible 2-way interactions between the significant main effects were tested. Variables with a significant association $(P<0.05)$ with the dependent variable were kept in the model. To obtain normally distributed residuals all the dependent variables were transformed using the natural logarithm or Box-Cox power transformation. The normality of the residuals was then tested (using quantile plots) after the analyses to confirm the correctness of the transformation, and the transformation that had the best fitted residuals was used. The model fit of the multivariable analyses was tested by visual examination of diagnostic plots according to Dohoo et al. (2010).

In addition, the Pearson correlation coefficient was calculated for the dependent variables, both for the IMI-negative data set and for the full data set with both IMI-negative and IMI-positive cows. All statistical analyses were performed using Stata Software (Stata Statistical Software: Release 13.1, 2010; StataCorp LP, College Station, TX).

\section{RESULTS}

\section{Bacteriological Findings}

In total, 11,867 milk samples from 976 cows were analyzed (Table 1). A total of 523 cows were classified as IMI negative (485 of these had no missing data), whereas 267 cows were classified as IMI positive (256 with no missing data; Table 2).

\section{Cow Factors}

The distribution of the independent variables for IMI-negative and IMI-positive cows are presented in Table 3.

\section{Whole-Udder Milk Samples}

The overall mean [and range (minimum-maximum)] of SCC, LDH, NAGase, and AP for IMI-negative cows was 137,000 cells $/ \mathrm{mL}(2,000-8,418,000$ cells $/ \mathrm{mL}), 1.73$ $\mathrm{U} / \mathrm{L}(0.15-12.0 \mathrm{U} / \mathrm{L}), 4.69 \mathrm{U} / \mathrm{L}(0.02-15.6 \mathrm{U} / \mathrm{L})$, and $643 \mathrm{U} / \mathrm{L}(50.4-3,519 \mathrm{U} / \mathrm{L})$, respectively. The overall mean (and range) of SCC, LDH, NAGase, and AP for IMI-positive cows was 480,000 cells/mL $(11,000$ 8,138,000 cells/mL), $2.63 \mathrm{U} / \mathrm{L}(0.48-20.4 \mathrm{U} / \mathrm{L}), 5.76$ $\mathrm{U} / \mathrm{L}(1.28-15.3 \mathrm{U} / \mathrm{L})$, and $636 \mathrm{U} / \mathrm{L}(55.0-2,618 \mathrm{U} / \mathrm{L})$, respectively.

\section{Associations Between Cow Factors and SCC}

Parity, breed, milk yield, percentage of milk fat, and concentration of milk urea were significantly $(P \leq$ 0.05) associated with Box-Cox SCC in both the IMInegative cow model (Table 4) and the model with all cows (Table 5). In general, SCC increased with increasing parity (Table 6); first-parity cows had significantly 
lower SCC than older cows. In the IMI-negative model, second-parity cows had lower SCC than cows in parity $\geq 3(P<0.001)$, whereas in the model with all cows, second-parity cows had lower SCC than cows in parity $\geq 4(P<0.001)$. Third-parity cows had lower SCC than cows in parity $\geq 5(P<0.001)$ in both models. In the IMI-negative cow model, fourth- and $\geq$ fifth-parity cows were not different $(P=0.11)$, but in the model with all cows, those parities were significantly different $(P=$ $0.02)$. In both models cows of SH breed had a higher SCC than cows of the SR breed. The SCC decreased with increasing milk yield and increasing milk urea concentration but increased with increasing percentage of milk fat in both models. Moreover, in the model with all cows, the associations between SCC and IMI status and between SCC and season were significant. The IMI-positive cows had a higher SCC than IMInegative cows and the SCC was higher in December to February compared with in September to November. Also, a tendency existed that the SCC was higher in March to April compared with in September to November $(P=0.051)$. The difference between the SCC in December to February compared with in March to April was not significant $(P=0.62)$. A significant interaction between milk urea concentration and breed was found in the IMI-negative model, where the SCC was reduced more per millimole per liter increase in milk urea for cows of the SH breed than for cows of the SR breed. In the model with all cows, a significant interaction between parity and milk yield was found; SCC was reduced more with increasing milk yield in cows in parity 2 and $\geq 5$ compared with first-parity cows and in cows in parity $\geq 5$ compared with cows in parity $4(P=$ $0.02)$. Least squares means for all the main effects are presented in Table 6 .

The null and reduced IMI-negative models were different by $23 \%$ in residual variance (i.e., the cow factors included in the reduced model explained $23 \%$ of the variation in SCC between cows; Table 4) of which parity represented approximately $15 \%$, breed $3 \%$, milk yield $3 \%$, percentage milk fat $0.8 \%$, and milk urea concentration $2 \%$. The difference between the null and reduced model with all cow was $42 \%$ (Table 5 ) of which IMI status represented approximately $23 \%$, parity $9 \%$, breed $1 \%$, milk yield $3 \%$, percentage milk fat $0.4 \%$, milk urea concentration $1 \%$, and season $0.6 \%$. The random effect of cows within herd was significant $(P=$ $0.02)$ in the IMI-negative model but not in the model with all cows.

\section{Associations Between Cow Factors and LDH}

Parity, DIM (transformed using fractional polynomial regression), concentration of milk urea, and period 
Table 3. Distribution [mean (SD) and range (minimum-maximum) for continuous variables and number of observations (percentage) for categorical variables] of udder-health indicators and cow factors for IMI-negative and IMI-positive cows

\begin{tabular}{|c|c|c|c|c|c|c|}
\hline \multirow[b]{2}{*}{ Item $^{1}$} & \multicolumn{3}{|c|}{ IMI negative $(\mathrm{n}=485)$} & \multicolumn{3}{|c|}{ IMI positive $(\mathrm{n}=256)$} \\
\hline & Mean (SD) & Range & No. $(\%)$ & Mean (SD) & Range & No. $(\%)$ \\
\hline $\mathrm{LDH}, \mathrm{U} / \mathrm{L}$ & $1.73(1.34)$ & $0.15-12.0$ & & $2.63(2.19)$ & $0.48-20.4$ & \\
\hline NAGase, U/L & $4.69(2.21)$ & $0.02-15.6$ & & $5.76(2.45)$ & $1.28-15.3$ & \\
\hline $\mathrm{AP}, \mathrm{U} / \mathrm{L}$ & $643(496)$ & $50-3519$ & & $636(474)$ & $55-2618$ & \\
\hline DIM & $137(98)$ & & & $143(95)$ & & \\
\hline Milk protein, $\%$ & $3.5(0.4)$ & & & $3.5(0.4)$ & & \\
\hline Milk urea, mmol/L & $4.6(1.3)$ & & & $4.4(1.4)$ & & \\
\hline \multicolumn{7}{|l|}{ Breed } \\
\hline Swedish Red & & & $261(54)$ & & & $126(49)$ \\
\hline Swedish Holstein & & & $224(46)$ & & & $130(51)$ \\
\hline \multicolumn{7}{|l|}{ Parity } \\
\hline First & & & $187(39)$ & & & $82(32)$ \\
\hline September-November & & & $218(45)$ & & & $90(35)$ \\
\hline December-February & & & $134(28)$ & & & $85(33)$ \\
\hline March-April & & & $133(27)$ & & & $81(32)$ \\
\hline
\end{tabular}

${ }^{1} \mathrm{LDH}=$ lactate dehydrogenase; NAGase $=\mathrm{N}$-acetyl- $\beta$-D-glucosaminidase; AP $=$ alkaline phosphatase.

of sampling were significantly associated with $\operatorname{lnLDH}$ activity both in the model with only IMI-negative cows (Table 4) and in the model with all cows (Table 5). In general, the LDH activity was significantly higher in cows in parity $\geq 5$ compared with cows in parity 1 to 4 in the IMI-negative model $(P<0.05)$ and compared with cows in parity 1 to 3 in the model with all cows $(P<0.01 ;$ Table 6$)$. In the IMI-negative model, cows in parity 2 to 4 had higher LDH activity compared with first-parity cows, but cows in parity 2 to 4 were not significantly different in LDH activity in any of the models $(P>0.05)$. In both models the LDH activity was high in early lactation, decreased until approximately 50 DIM, and increased continuously after 100 DIM (Figure 1). The LDH activity decreased with increasing milk urea concentrations in both models. Moreover, in both models the LDH activity was significantly lower in September to November compared with in December to February or March to April. Levels in December to February and March to April were not significantly different $(P>0.40)$. In the IMI-negative model, significantly increased LDH activity was seen with increasing percentages of milk protein, whereas in the model with all cows, a significant increase in LDH activity was seen with increasing percentages of milk fat. In addition, in the model with all cows, significantly decreased LDH activity was seen with increasing milk yield. A significant association between LDH and IMI status was seen in the model with all cows, where the LDH activity was higher in IMI-positive cows com- pared with IMI-negative cows. Least squares means for all the main effects are presented in Table 6 .

A difference of $35 \%$ (Table 4) was seen in the residual variance between the null and the reduced IMI-negative model of which parity represented approximately $6 \%$, DIM $7 \%$, milk urea concentration $3 \%$, percentage of milk protein $1 \%$, and season $3 \%$. The difference between the null and reduced model with all cow was $38 \%$ (Table 5), of which IMI status represented approximately $7 \%$, parity $6 \%$, DIM $4 \%$, milk yield $1 \%$, percentage milk fat $0.6 \%$, milk urea concentration $2 \%$, and season $2 \%$. The random effect of cows within herd was significant $(P<0.001)$ for both models.

\section{Associations Between Cow Factors and NAGase}

Parity, milk yield (transformed using fractional polynomial regression in the model with all cows), DIM (transformed using fractional polynomial regression in both models), milk urea concentration, and period of sampling were significantly associated with lnNAGase activity in both the model with IMI-negative cows (Table 4) and in the model with all cows (Table 5). In general, NAGase was significantly lower for first-parity cows compared with older cows in both models (Table 6 ), and in the model with all cows, the NAGase activity was significant lower for cows in parity 2 compared with older cows $(P<0.05)$ but not between cows in higher parities $(P>0.05)$. In the model with IMI-negative cows, the NAGase activity was significantly lower in 
Table 4. Final multivariable mixed-effect linear regression model of cow factors associated with SCC $\{\times 1,000 / \mathrm{mL}$, Box-Cox (bc) power transformed $[(\mathrm{SCC}-0.1232737-1) /-0.1232737]\}$, lactate dehydrogenase $[\mathrm{LDH}(\mathrm{U} / \mathrm{L})$, transformed using the natural logarithm], N-acetyl- $\beta$-D-glucosaminidase [NAGase (U/L) +1.222117 and transformed using the natural logarithm], and alkaline phosphatase $\mathrm{AP}(\mathrm{U} / \mathrm{L})$, transformed using the natural logarithm] of 485 IMI-negative Swedish dairy cows

\begin{tabular}{|c|c|c|c|c|c|c|c|c|c|c|c|c|}
\hline \multirow[b]{2}{*}{ Variable } & \multicolumn{3}{|c|}{ bcSCC } & \multicolumn{3}{|c|}{$\operatorname{lnLDH}$} & \multicolumn{3}{|c|}{ lnNAGase } & \multicolumn{3}{|c|}{$\ln \mathrm{AP}$} \\
\hline & $\beta^{1}$ & $\mathrm{SE}(\beta)$ & $P$-value & $\beta$ & $\mathrm{SE}(\beta)$ & $P$-value & $\beta$ & $\mathrm{SE}(\beta)$ & $P$-value & $\beta$ & $\mathrm{SE}(\beta)$ & $P$-value \\
\hline Intercept & 2.69 & 0.06 & - & 0.04 & 0.08 & - & 1.44 & 0.04 & - & 6.56 & 0.06 & - \\
\hline \multicolumn{13}{|l|}{ Parity } \\
\hline First & Ref. $^{2}$ & & - & Ref. & & - & Ref. & & - & Ref. & & - \\
\hline Second & 0.38 & 0.07 & $<0.001$ & 0.19 & 0.05 & $<0.001$ & 0.16 & 0.03 & $<0.001$ & -0.32 & 0.06 & $<0.001$ \\
\hline Third & 0.43 & 0.09 & $<0.001$ & 0.13 & 0.06 & 0.022 & 0.20 & 0.04 & $<0.001$ & -0.57 & 0.07 & $<0.001$ \\
\hline Fourth & 0.65 & 0.10 & $<0.001$ & 0.27 & 0.07 & $<0.001$ & 0.26 & 0.05 & $<0.001$ & -0.51 & 0.08 & $<0.001$ \\
\hline$\geq$ Fifth & 0.88 & 0.12 & $<0.001$ & 0.50 & 0.09 & $<0.001$ & 0.30 & 0.06 & $<0.001$ & -0.50 & 0.09 & $<0.001$ \\
\hline \multicolumn{13}{|l|}{ Breed } \\
\hline Swedish Red (SR) & Ref. & & - & & & & & & & Ref. & & - \\
\hline Swedish Holstein (SH) & 0.24 & 0.06 & $<0.001$ & & & & & & & 0.26 & 0.04 & $<0.001$ \\
\hline $\mathrm{DIM}^{-1}$ & & & & 0.06 & 0.01 & $<0.001$ & & & & & & \\
\hline DIM $^{1}$ & & & & 0.22 & 0.03 & $<0.001$ & & & & & & \\
\hline $\mathrm{DIM}^{-0.5}$ & & & & & & & 0.18 & 0.02 & $<0.001$ & & & \\
\hline $\mathrm{DIM}^{2}$ & & & & & & & 0.02 & 0.006 & 0.001 & & & \\
\hline $\mathrm{DIM}^{-0.5}$ & & & & & & & & & & -2.05 & 0.21 & $<0.001$ \\
\hline $\mathrm{DIM}^{-0.5} \times \ln (\mathrm{DIM})$ & & & & & & & & & & -0.46 & 0.07 & $<0.001$ \\
\hline Milk yield, $\mathrm{kg}$ of milk & -0.02 & 0.004 & $<0.001$ & & & & -0.006 & 0.002 & 0.002 & 0.008 & 0.004 & 0.025 \\
\hline Milk fat, $\%$ & 0.14 & 0.05 & 0.004 & & & & & & & 0.10 & 0.04 & 0.016 \\
\hline Milk protein, $\%$ & & & & 0.23 & 0.07 & 0.002 & & & & 0.25 & 0.09 & 0.006 \\
\hline Milk urea, mmol/L & -0.01 & 0.03 & 0.59 & -0.09 & 0.02 & $<0.001$ & -0.07 & 0.01 & $<0.001$ & -0.06 & 0.02 & 0.004 \\
\hline \multicolumn{13}{|l|}{ Season } \\
\hline September-November & & & & Ref. & & - & Ref. & - & - & & & \\
\hline December-February & & & & 0.22 & 0.06 & $<0.001$ & 0.17 & 0.04 & $<0.001$ & & & \\
\hline March-April & & & & 0.18 & 0.05 & $<0.001$ & 0.13 & 0.03 & $<0.001$ & & & \\
\hline \multicolumn{13}{|l|}{ Interaction } \\
\hline SR breed $\times$ milk urea, mmol/L & Ref. & - & - & & & & & & & & & \\
\hline SH breed $\times$ milk urea, $\mathrm{mmol} / \mathrm{L}$ & -0.09 & 0.04 & 0.029 & & & & & & & & & \\
\hline Random effect herd (full model), variance (SE) & & $0.014(0.0$ & 10) & & $0.136(0.04$ & & & $0.022(0.008)$ & & & $0.030(0.012)$ & \\
\hline Random effect residuals (full model), variance (SE) & & $0.363(0.0$ & 24) & & $0.180(0.01$ & & & $0.083(0.005)$ & & & $0.212(0.014)$ & \\
\hline Random effect herd (null model), variance (SE) & & $0.0001(0$. & $.006)$ & & $0.123(0.03$ & & & $0.012(0.005)$ & & & $0.028(0.016)$ & \\
\hline Random effect residuals (null model), variance (SE) & & $0.471(0.0$ & $31)$ & & $0.275(0.01$ & & & $0.119(0.008)$ & & & $0.559(0.037)$ & \\
\hline \multicolumn{13}{|l|}{${ }^{1} \beta=$ regression coefficient. } \\
\hline
\end{tabular}


Table 5. Final multivariable mixed-effect linear regression model of cow factors associated with SCC $\{\times 1,000 / \mathrm{mL}$, Box-Cox (bc) power transformed $[(\mathrm{SCC}-0.1232737-1) /-0.1232737]\}$ lactate dehydrogenase $[\mathrm{LDH}(\mathrm{U} / \mathrm{L})$, transformed using the natural logarithm], N-acetyl- $\beta$-D-glucosaminidase [NAGase (U/L) +1.222117 and transformed using the natural (orithm, and alkaline phosphatase [AP (U/L), transformed using the natural logarithm] of 741 Swedish dairy cows with different IMI status

\begin{tabular}{|c|c|c|c|c|c|c|c|c|c|c|c|c|}
\hline \multirow[b]{2}{*}{ Variable } & \multicolumn{3}{|c|}{$\mathrm{bcSCC}$} & \multicolumn{3}{|c|}{$\operatorname{lnLDH}$} & \multicolumn{3}{|c|}{ lnNAGase } & \multicolumn{3}{|c|}{$\ln \mathrm{AP}$} \\
\hline & $\beta^{1}$ & $\mathrm{SE}(\beta)$ & $P$-value & $\beta$ & $\operatorname{SE}(\beta)$ & $P$-value & $\beta$ & $\operatorname{SE}(\beta)$ & $P$-value & $\beta$ & $\mathrm{SE}(\beta)$ & $P$-value \\
\hline Intercept & 2.72 & 0.06 & - & 0.07 & 0.08 & - & 1.51 & 0.04 & - & 6.53 & 0.05 & - \\
\hline \multicolumn{13}{|l|}{ IMI status } \\
\hline Negative & Ref. $^{2}$ & & - & Ref. & & - & Ref. & & - & & & \\
\hline Positive & 0.79 & 0.05 & $<0.001$ & 0.33 & 0.04 & $<0.001$ & 0.11 & 0.02 & $<0.001$ & & & \\
\hline $\begin{array}{r}\text { Parity } \\
\text { First }\end{array}$ & Ref. & & - & Ref. & & - & Ref. & & - & Ref. & & - \\
\hline Second & 0.27 & 0.06 & $<0.001$ & 0.25 & 0.04 & $<0.001$ & $\begin{array}{l}\text { nel. } \\
0.13\end{array}$ & 0.03 & $<\overline{0.001}$ & -0.26 & 0.04 & $<0.001$ \\
\hline Third & 0.36 & 0.07 & $<0.001$ & 0.28 & 0.05 & $<0.001$ & 0.20 & 0.03 & $<0.001$ & -0.51 & 0.06 & $<0.001$ \\
\hline Fourth & 0.52 & 0.08 & $<0.001$ & 0.36 & 0.06 & $<0.001$ & 0.24 & 0.04 & $<0.001$ & -0.51 & 0.06 & $<0.001$ \\
\hline$\geq$ Fifth & 0.77 & 0.09 & $<0.001$ & 0.50 & 0.07 & $<0.001$ & 0.29 & 0.05 & $<0.001$ & -0.58 & 0.07 & $<0.001$ \\
\hline \multicolumn{13}{|l|}{ Breed } \\
\hline Swedish Red & Ref. & & - & & & & & & & Ref. & & - \\
\hline Swedish Holstein & 0.19 & 0.04 & $<0.001$ & & & & & & & 0.25 & 0.03 & $<0.001$ \\
\hline DIM $^{-1}$ & & & & & & & 0.03 & 0.004 & $<0.001$ & & & \\
\hline $\mathrm{DIM}^{-0.5}$ & & & & 0.63 & 0.09 & $<0.001$ & & & & & & \\
\hline $\operatorname{lnDIM}$ & & & & 0.50 & 0.07 & $<0.001$ & & & & 0.55 & 0.03 & $<0.001$ \\
\hline Milk yield, $\mathrm{kg}$ milk & -0.001 & 0.006 & 0.821 & -0.01 & 0.003 & $<0.001$ & & & & & & \\
\hline Milk yield ${ }^{-0.5}, \mathrm{~kg}$ milk & & & & & & & 0.13 & 0.26 & 0.616 & & & \\
\hline Milk fat, $\%$ & 0.11 & 0.04 & 0.002 & 0.08 & 0.03 & 0.008 & & & & 0.07 & 0.03 & 0.024 \\
\hline $\begin{array}{l}\text { Milk protein, } \% \\
\text { Milk urea mmol/L }\end{array}$ & & & & & & & & & & 0.24 & 0.06 & $<0.001$ \\
\hline & 0.02 & 0.028 \\
\hline $\begin{array}{l}\text { Season } \\
\text { September-November }\end{array}$ & Ref. & & & & & & & & & & & \\
\hline December-February & 0.14 & 0.06 & 0.014 & 0.14 & 0.05 & 0.006 & 0.13 & 0.03 & $<0.001$ & 0.05 & 0.05 & 0.260 \\
\hline March-April & 0.11 & 0.05 & 0.051 & 0.18 & 0.05 & $<0.001$ & 0.11 & 0.03 & $<0.001$ & -0.10 & 0.04 & 0.026 \\
\hline \multicolumn{13}{|l|}{ Interaction } \\
\hline Parity $1 \times$ milk yield & Ref. & & - & & & & & & & & & \\
\hline Parity $2 \times$ milk yield & -0.02 & 0.008 & 0.035 & & & & & & & & & \\
\hline Parity $3 \times$ milk yield & -0.01 & 0.008 & 0.088 & & & & & & & & & \\
\hline Parity $4 \times$ milk yield & -0.008 & 0.009 & 0.382 & & & & & & & & & \\
\hline Parity $5 \times$ milk yield & -0.03 & 0.01 & 0.002 & & & & & & & & & \\
\hline Parity $1 \times$ milk yield $^{-0.5}$ & & & & & & & Ref. & & - & & & \\
\hline Parity $2 \times$ milk yield $^{-0.5}$ & & & & & & & 0.80 & 0.31 & 0.011 & & & \\
\hline Parity $3 \times$ milk yield $^{-0.5}$ & & & & & & & 0.84 & 0.34 & 0.014 & & & \\
\hline Parity $4 \times$ milk yield ${ }^{-0.5}$ & & & & & & & 1.37 & 0.40 & 0.001 & & & \\
\hline Parity $5 \times$ milk yield $^{-0.5}$ & & & & & & & 0.70 & 0.42 & 0.092 & & & \\
\hline Parity $1 \times \operatorname{lnDIM}$ & & & & & & & & & & Ref. & & - \\
\hline Parity $2 \times \operatorname{lnDIM}$ & & & & & & & & & & -0.03 & 0.04 & 0.430 \\
\hline Parity $3 \times \operatorname{lnDIM}$ & & & & & & & & & & -0.17 & 0.05 & $<0.001$ \\
\hline Parity $4 \times \operatorname{lnDIM}$ & & & & & & & & & & -0.20 & 0.06 & 0.002 \\
\hline Parity $5 \times \operatorname{lnDIM}$ & & & & & & & & & & -0.10 & 0.08 & 0.197 \\
\hline Random effect herd (full model), variance (SE) & \multicolumn{3}{|c|}{$0.005(0.005)$} & \multicolumn{3}{|c|}{$0.135(0.040)$} & \multicolumn{3}{|c|}{$0.016(0.005)$} & \multicolumn{3}{|c|}{$0.025(0.009)$} \\
\hline Random effect residuals (full model), variance (SE) & \multirow{2}{*}{\multicolumn{3}{|c|}{$0.341(0.018)$}} & \multicolumn{3}{|c|}{$0.206(0.011)$} & \multicolumn{3}{|c|}{$0.085(0.005)$} & \multicolumn{3}{|c|}{$0.215(0.011)$} \\
\hline Random effect herd (null model), variance (SE) & & & & \multirow{2}{*}{\multicolumn{3}{|c|}{$\begin{array}{l}0.111(0.035) \\
0.332(0.018)\end{array}$}} & & $0.111(0.0$ & & & $0.026(0.01$ & \\
\hline Random effect residuals (null model), variance (SE) & \multicolumn{3}{|c|}{$0.593(0.031)$} & & & & & $0.332(0.0$ & & & $0.541(0.02$ & \\
\hline
\end{tabular}

\footnotetext{
${ }^{1} \beta=$ regression coefficient.
}

${ }^{2}$ Ref. $=$ reference category. 

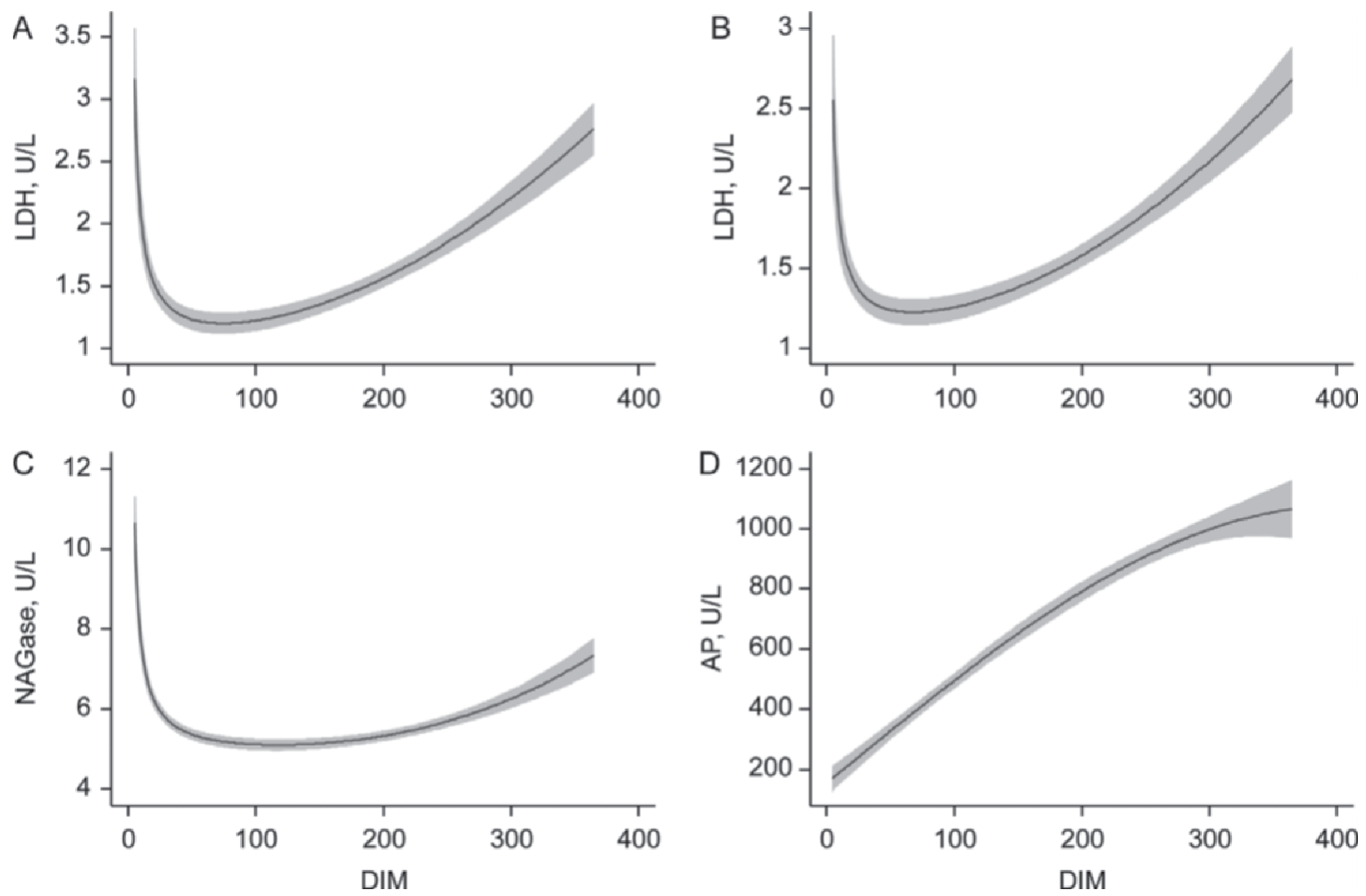

Figure 1. Two-way fractional-polynomial prediction plot (including 95\% CI) of lactate dehydrogenase (LDH) activity over DIM for IMInegative cows only $(\mathrm{n}=485, \mathrm{~A})$ and for both IMI-negative and IMI-positive cows $(\mathrm{n}=741 \mathrm{~B})$, of N-acetyl- $\beta$-D-glucosaminidase (NAGase) activity over DIM for IMI-negative cows $(\mathrm{n}=485, \mathrm{C})$, and of alkaline phosphatase $(\mathrm{AP})$ activity over DIM for IMI-negative cows $(\mathrm{n}=485, \mathrm{D})$.

cows in parity 2 than in cows in parity $\geq 5(P=0.02)$, but no difference was observed between cows in parity 2 and cows in parity 3 to $4(P>0.05)$. Moreover, in the IMI-negative model, the NAGase activity was high in early lactation, decreased until approximately 40 DIM when it stabilized, and then started to increase at approximately 160 DIM (Figure 1). For the model with all cows, the NAGase activity decreased with increasing DIM (Table 6). A decreased NAGase activity was seen with increasing milk urea concentrations in both models. As for the LDH activity, the NAGase activity was significantly lower in September to November compared with in December to February and March to April. Levels in December to February and March to April were not significantly different $(P>0.34)$. Also, the association between milk yield and NAGase activity was similar in both models; the NAGase activity significantly decreased with increasing milk yield (for the model with all cows, the NAGase activity increased with increasing milk yield ${ }^{-0.5}$ but as an increasing milk yield $^{-0.5}$ is equal to a decreasing true milk yield, the association is as in the IMI-negative model). In the model with all cows, a significant association was seen between NAGase activity and IMI status, where the NAGase activity was higher in IMI-positive cows than IMI-negative cows. Moreover, a significant interaction between parity and milk yield was seen in the model with all cows, where the NAGase activity decreased more per increase in milk yield for cows in parity 2 to 4 compared with first-parity cows. Least squares means for all the main effects are presented in Table 6 .

A difference of $31 \%$ (Table 4) was seen in the residual variance between the null and reduced IMI-negative model of which parity and DIM represented approximately $8 \%$ each, milk yield $1.5 \%$, milk urea concentration $5 \%$, and season $4 \%$. The difference between the null and reduced model with all cows was $31 \%$ (Table 5 ), of which IMI status represented approximately $2 \%$, parity $11 \%$, DIM $6 \%$, milk yield $6 \%$, milk urea concentration $3 \%$, and season $2 \%$. The random effect of cows within herd was significant $(P<0.001)$ for both models. 


\section{Associations Between Cow Factors and AP}

Parity, breed, DIM (transformed using fractional polynomial regression), percentage of milk protein, percentage of milk fat, and milk urea concentration were significantly associated with $\ln \mathrm{AP}$ activity both in the model with IMI-negative cows (Table 4) and in the model with all cows (Table 5). In general, the AP activity was higher in first- and second-parity cows compared with older cows $(P<0.05)$, and first-parity cows had also significantly higher AP activity than second-parity cows in both models (Table 6). No significant differences existed in AP activity between cows in parity $\geq 3$ in any model $(P>0.34)$. In both models the AP activity of cows of the $\mathrm{SH}$ breed was higher than for cows of the SR breed, and an increasing AP activity was seen with increasing DIM (Table 6 and Figure 1). Moreover, in both models the AP activity increased with increasing percentages of milk fat and milk protein and decreased with increasing milk urea concentrations. The AP activity increased with increasing milk yield in the IMI-negative model. In the model with all cows, no significant association was found between AP activity and IMI status. However, the association between AP activity and season was significant, and a significant interaction between parity and DIM was also found. The AP activity was significantly lower in March to April compared with in September to November and December to February $(P=0.005)$. Levels in September to November and December to February did not differ significantly $(P=0.26)$. Moreover, the AP activity decreased significantly with increasing DIM in cows in parity 3 and 4 compared with in cows in parity 1 and $2(P=0.001)$. Least squares means for all main effects are presented in Table 6 .

A difference of $62 \%$ (Table 4 ) was seen in the residual variance between the null and the reduced IMI-negative model of which parity represented approximately $8 \%$, breed $3 \%$, DIM $36 \%$, milk yield $0.4 \%$, percentage of milk protein $0.6 \%$, percentage of milk fat $0.4 \%$, and milk urea concentration $0.9 \%$. In the model with all cows, the difference between the full and reduced model was $60 \%$ (Table 5), of which parity represented approximately $8 \%$, breed $3 \%$, DIM $38 \%$, percentage of milk protein $0.9 \%$, percentage of milk fat $0.2 \%$, milk urea concentration $0.2 \%$, and season $0.6 \%$. The random effect of cows within herd was significant $(P<0.001)$ in both models.

\section{Correlations Between Dependent Variables (Observed Values)}

The highest correlation $(\mathrm{r}=0.59)$ was seen between $\operatorname{lnSCC}$ and $\operatorname{lnLDH}$ when data from all cows were used.
When data from only the IMI-negative cows were used, the correlation between $\operatorname{lnSCC}$ and $\operatorname{lnLDH}$ was 0.53 . The correlation between $\operatorname{lnSCC}$ and lnNAGase was 0.45 when data from all cows were used and 0.39 when data from only the IMI-negative cows were used. Between $\operatorname{lnSCC}$ and $\ln \mathrm{AP}$ the correlation was 0.06 when data from all cows were used and 0.08 when data from only IMI-negative cows were used. Between $\operatorname{lnLDH}$ and lnNAGase the correlation was 0.46 when data from all cows were used and 0.39 when data from only IMI-negative cows were used. The correlation between $\operatorname{lnLDH}$ and $\ln \mathrm{AP}$ was 0.10 and between $\ln N A G a s e$ and $\ln \mathrm{AP}$ 0.006 when data from all cows were used and 0.12 and 0.04 , respectively, when data from only IMI-negative cows were used.

\section{Model Fit}

All models showed reasonable fit according to the visual examination of the diagnostic plots.

\section{DISCUSSION}

Our results confirmed the hypothesis that cow factors affect SCC, LDH, NAGase, and AP. However, the cow factors that were significantly associated with CMSCC only explained $23 \%$ of the variation in CMSCC between IMI-negative individuals in the selected population, whereas the cow factors that were significantly associated with LDH, NAGase, and AP explained more $(>30 \%)$ of the variation in LDH, NAGase, and AP. Hence, our hypothesis that LDH, NAGase, and AP should be less affected by cow factors and then potentially more clearly reflect udder inflammation due to IMI can be discarded. A relatively low amount of the variation in the udder-health indicators could be explained by the included cow factors, which indicates that other factors exist that we were not able to measure or take into account that also have an effect. More research is needed to find those factors, because the diagnostic properties of the indicators could be improved if they can be identified.

One other factor that could partly explain the relatively low proportion of the variation explained by the cow factors in the IMI-negative model could be that not all cows included were truly IMI negative. Some of the variation in the indicators would then be due to inflammatory status and not only due to differences in cow factors. As our prime interest was to identify systematic effects on udder-health indicators in healthy cows, we wanted to be as sure as possible that the cow was IMI negative. Hence, our definition of an IMI-negative cow was having all quarters bacteriologically negative at 3 consecutive samplings $1 \mathrm{~d}$ apart. However, neither 
the Se nor Sp of bacteriology is $100 \%$. Bacteria with low viability will not grow in culture; consequently, a cow with an IMI could be classified as false negative. The probability that an IMI-positive quarter would be missed when 3 consecutive samplings are used is, however, low (Dohoo et al., 2011a,b). Some of the IMI-negative cows in this study had high CMSCC (about 10\% had a CMSCC >200,000 cells $/ \mathrm{mL}$ ) at the test milking, which is an indication of subclinical mastitis and that those cows might not truly be IMI negative. However, removing those $10 \%$ did not improve the model nor increase the amount of variation explained by the cow factors (results not shown).

For all the udder-health indicators, the models including all cows explained a higher amount of variation than the models including only IMI-negative cows, which is similar to what Schepers et al. (1997) found. If the variation explained in the models with all cows is compared between the udder-health indicators, the amount of variation explained by IMI status was highest in the CMSCC model (23\%), and only 7 and $2 \%$, respectively, of the variation in LDH and NAGase could be explained by IMI status. This indicates that CMSCC has the best potential, of the udder-health indicators investigated, as a diagnostic tool in finding cows with IMI because an IMI will cause a substantial change in CMSCC. In the present study we could not find any significant association between AP and IMI. To our knowledge no investigations of AP and IMI have been published, but others have shown significant associations between AP and subclinical mastitis (defined by California Mastitis Test; Babaei et al., 2007) and associations between AP and acute clinical mastitis (Bogin and Ziv, 1973).

The significant associations between the independent and dependent variables found in the IMI-negative model and in the model with all cows remained mostly the same, but some variables were excluded and some were added in the model with all cows included. Of the independent variables included, only parity and milk urea were associated with all udder-health indicators in both the IMI-negative model and the model including all cows.

The association between parity and CMSCC, LDH, and NAGase showed all increasing values with increasing parity and for AP decreasing values with increasing parity. However, it was only first-parity cows that differed significantly compared with older cows for all udder-health indicators. Because most first-parity cows have not experienced mastitis or machine milking, their udder should, in general, be healthier and in better condition than in older cows. Older cows are more likely to have experienced periods of mastitis and a longer time of machine milking, both of which could lead to persistent udder damage causing a state of nonbacterial inflammation. This could explain some of the differences in CMSCC as well as some of the differences in LDH, NAGase, and AP between cows in different parities. Increasing SCC with increasing parities has been shown by others (Brolund, 1985; Vecht et al., 1989; Schepers et al., 1997), whereas Laevens et al. (1997) and Natzke et al. (1972) did not find such an association in IMI-negative cows. However, the study by Laevens et al. (1997) only included 4 cows in parity 3 and no cows in higher parities, which could explain the lack of association.

In our study, first-parity cows had lower LDH and NAGase activity and higher AP activity compared with older cows. Mattila et al. (1986) did also find lower NAGase activities in composite milk samples from first-parity cows compared with older cows, whereas Piccinini et al. (2007) found higher NAGase activity in IMI-negative quarters of first-parity cows compared with older cows (though the SCC did not differ significantly). Chagunda et al. (2006) did not find any association between parity and NAGase activity, LDH activity, or SCC in healthy (SCC $<100,000$ cells $/ \mathrm{mL}$ and no clinical mastitis) cows, but they found an association with parity in cows with clinical mastitis, with increasing levels in all the udder-health indicators investigated with increasing parity. As NAGase is a lysosomal enzyme that is released into milk from neutrophils during phagocytosis and cell lysis, and to some extent from damaged epithelial cells (Kitchen et al., 1978), an increased activity could be likely for older cows. Lactate dehydrogenase is present in most tissues in the body but also in the cytoplasm leukocytes and will also be released into milk at cell damages (Kitchen, 1981). In line with our findings, Cozzi et al. (2011) found significantly higher AP activity in blood of healthy (no signs of clinical disease) first-parity Holstein cows compared with multiparous cows of the same breed. Alkaline phosphatase is an endogenous enzyme in milk and is associated with microsomal particles (Larsen et al., 2010). To our current knowledge nothing is written about the effects of cow factors on AP activity.

In accordance with other studies (Godden et al., 2001; Arunvipas et al., 2003; Nyman et al., 2009), we found a negative association with milk urea concentration and SCC. To our knowledge, the association between bovine milk urea concentration and $\mathrm{LDH}$, NAGase, or AP activities in milk is scarcely described. In humans, urea has been shown to inhibit serum LDH levels (Emerson and Wilkinson, 1965), and a negative correlation has been found between bovine milk urea and milk NAGase (Grabowski, 2000). Milk urea nitrogen concentration reflects the protein status of the cow and can be affected by the fat-protein balance in 
the feed (Oltner and Wiktorsson, 1983; Oltner et al., 1985). If the amount of energy supplied in the feed is adequate, milk urea nitrogen is indicative for protein status, i.e., higher levels with excess protein provided and lower levels with deficit levels of protein (Roseler et al., 1993), but also type of protein fed will affect the protein status (Baker et al., 1995).

The associations found in the present study between DIM, and LDH or NAGase were similar to the findings of Chagunda et al. (2006). Unlike in our study, they also found a significant association between SCC and DIM, which others also have shown (Brolund, 1985; Laevens et al., 1997; Schepers et al., 1997). However, in other studies of healthy cows (IMI negative), no association between DIM and SCC has been found (Natzke et al., 1972; Laevens et al., 1997). In the univariable analysis of the present study (results not shown), DIM was significantly associated with SCC, but the association became nonsignificant in the multivariable analysis when milk yield was included, indicating an effect of dilution. Others have also seen a reduced effect of DIM when milk production was included in their statistical models (Syrstad and Røn, 1979; Jaartsveld et al., 1983). Mattila et al. (1986) found a similar association between NAGase activity and stage of lactation as the one found in the present study between NAGase and DIM, with very high levels early in lactation that dropped quickly to then slowly starting to increase again.

Milk yield was associated with SCC and NAGase in both models, with LDH in the model with all cows and with AP in the IMI-negative model. Our finding that SCC decreased with increasing milk yield is in line with previous studies of both IMI-negative cows and IMI-positive cows (Jaartsveld et al., 1983). The most common explanation to a decreased SCC with higher milk yields is the dilution effect (Jaartsveld et al., 1983; Emanuelson et al., 1988; Green et al., 2006). In line with our findings, Mattila et al. (1986) showed a decreased NAGase activity with increasing milk yields.

In accordance with the study by Brolund (1985) and a more recent study (Nyman et al., 2009), we found a significant difference in CMSCC between the 2 main Swedish dairy breeds. The IMI-negative cows of the SH breed seem to have a naturally higher SCC compared with cows of the SR breed. Cows of the SH breed had also higher AP concentrations in milk compared with cows of the SR breed. The differences in CMSCC and AP between cows of the SH breed and SR breed are most likely genetic, because differences in udder health, both in SCC and in incidence of clinical mastitis, between the breeds have been reported repeatedly during the last decades (Bendixen et al., 1988; Emanuelson et al., 1993; Nyman et al., 2009). Possible explanations could be related to morphological differences, such as udder and teat shape, but also to differences in immune function (Nyman et al., 2008). Others have also found significant associations between breed and SCC (Vecht et al., 1989) showing higher CMSCC in the Dutch Meuse Rhine Yssel breed compared with Dutch Friesian/Holstein Friesian breeds. In contrast to that study and our findings, Chagunda et al. (2006) could not find any association between breed (Danish Holstein, Danish Red, and Jersey) and SCC of healthy cows. However, they found a significant association between breed and LDH and between breed and NAGase, where Jersey cows had higher LDH and NAGase activity compared with Danish Holsteins and Danish Reds. The breed difference in AP, found in the present study, has to our knowledge not been shown previously.

Similar to our findings, Chagunda et al. (2006) showed an association between month of the year and LDH and NAGase, both indicators having their highest values during January to April and their lowest values during September to November. In our study CMSCC in the model with all cows and the LDH and NAGase activities in both models were lowest in September to November compared with December to February and March to April, whereas AP was lowest in March to April compared with in September to November and December to February. A significant association between season and these indicators, but not between season and SCC in the IMI-negative model, indicates that the increase or decrease in LDH and NAGase in IMI-negative cow is not due to a difference in udder infections between seasons. In Sweden, legislation states that cows must be on pasture during the summer months, and evidence exists of improved health if grazing is provided (Burow et al., 2013). Hence, the low levels of SCC, LDH, and NAGase in September to November might be reflecting this improved general health, which then deteriorates somewhat during the housing season.

Associations between milk fat and milk protein, and SCC, LDH, NAGase, and AP in composite milk samples of IMI-negative cows have, to our knowledge, have rarely been described in the literature, but recently it has been shown that the association between milk metabolites and SCC is strong (Sundekilde et al., 2013). The compositional change in milk due to mastitis has been more thoroughly described (Kitchen et al., 1978; Harmon, 1994; Forsback et al., 2009). However, some studies have found positive correlations between logSCC and total milk fat content and also between $\operatorname{logSCC}$ and total milk protein content (Lindmark-Månsson et al., 2000; Berglund et al., 2007). Milk composition is affected by feeding, among other things, and indications exist that feeding also affects SCC (Svensson et al., 2006; Nyman et al., 2009); hence, it is likely that LDH, NAGase, and AP also could be affected by feeding. 
The correlations found between the observed values of SCC and LDH and NAGase in the present study are in line with those found by Chagunda et al. (2006) but generally somewhat lower. As shown by Chagunda et al. (2006), the correlations between the observed values were higher for mastitic cows than healthy cows or, as in our case, higher when all cows were considered compared with when only IMI-negative cows were considered.

Whether adjusting the udder-health indicators according to cow factor associations found in the present study will improve the diagnostic features of the udderhealth indicators to identify udder infections will be addressed in the next part of the current project.

\section{CONCLUSIONS}

Several cow factors were associated with the CMSCC of IMI-negative dairy cows, and those factors explained approximately $23 \%$ of the variation in CMSCC in the selected population. Several cow factors were, to the same or a greater extent than the CMSCC, also associated with milk LDH, NAGase, and AP. All udderhealth indicators except AP were associated with IMI status. The IMI status explained more of the variation in CMSCC than in LDH and NAGase. Further studies are needed to investigate whether the diagnostic properties of these udder-health indicators will improve of an adjustment according to their associations with different cow factors when used as a diagnostic tool for finding cows with IMI.

\section{ACKNOWLEDGMENTS}

The authors gratefully acknowledge the financial support from the Swedish Farmers' Foundation for Agricultural Research (Stockholm, Sweden). We especially thank all the participating farmers for their hospitality and cooperation; the technicians for invaluable assistance in sampling; and the technical staff at the laboratory at the Department of Animal Health and Antimicrobial Strategies (SVA, Uppsala, Sweden), the Department of Bacteriology (SVA, Uppsala, Sweden), and the Department of Animal Science (Aarhus University, Tjele, Denmark).

\section{REFERENCES}

Artursson, K., M. Nilsson-Ost, and K. Persson Waller. 2010. An improved method to culture Staphylococcus aureus from bovine milk. J. Dairy Sci. 93:1534-1538.

Arunvipas, P., I. R. Dohoo, J. A. VanLeeuwen, and G. P. Keefe. 2003 The effect of non-nutritional factors on milk urea nitrogen levels in dairy cows in Prince Edward Island, Canada. Prev. Vet. Med. 59:83-93.
Babaei, H., L. Mansouri-Najand, M. M. Molaei, A. Kheradmand, and M. Sharifan. 2007. Assessment of lactate dehydrogenase, alkaline phosphatase and aspartate aminotransferase activities in cow's milk as an indicator of subclinical mastitis. Vet. Res. Commun. $31: 419-425$

Baker, L. D., J. D. Ferguson, and W. Chalupa. 1995. Responses in urea and true protein of milk to different protein feeding schemes for dairy cows. J. Dairy Sci. 78:2424-2434.

Bendixen, P. H., B. Vilson, I. Ekesbo, and D. B. Åstrand. 1988. Disease frequencies in dairy cows in Sweden, V. Mastitis Prev. Vet. Med. 5:263-274.

Berglund, I., G. Pettersson, K. Östensson, and K. SvennerstenSjaunja. 2007. Quarter milking for improved detection of increased SCC. Reprod. Domest. Anim. 42:427-432.

Berning, L. M., and G. E. Shook. 1992. Prediction of mastitis using milk somatic cell count, $\mathrm{N}$-acetyl-beta-D-glucosaminidase, and lactose. J. Dairy Sci. 75:1840-1848.

Bogin, E., and G. Ziv. 1973. Enzymes and minerals in normal and mastitic milk. Cornell Vet. 63:666-676.

Brolund, L. 1985. Cell counts in bovine milk. Causes of variation and applicability for diagnosis of subclinical mastitis. Acta Vet. Scand. Suppl. 80:1-123.

Brolund, L. 1990. Technical Utilization of Cell Count in the MilkRecording Service (Cellhaltens Tekniska Utnyttjande i Kokontrollen). Swedish Assoc. Livest. Breed. Prod., Eskilstuna, Sweden.

Burow, E., T. Rousing, P. T. Thomsen, N. D. Otten, and J. T. Sorensen. 2013. Effect of grazing on the cow welfare of dairy herds evaluated by a multidimensional welfare index. Animal 7:834-842.

Chagunda, M. G., T. Larsen, M. Bjerring, and K. L. Ingvartsen. 2006 L-lactate dehydrogenase and N-acetyl-beta-D-glucosaminidase activities in bovine milk as indicators of non-specific mastitis. J. Dairy Res. 73:431-440.

Cozzi, G., L. Ravarotto, F. Gottardo, A. L. Stefani, B. Contiero, L. Moro, M. Brscic, and P. Dalvit. 2011. Short communication: Reference values for blood parameters in Holstein dairy cows: Effects of parity, stage of lactation, and season of production. J. Dairy Sci. 94:3895-3901

Dohoo, I., S. Andersen, R. Dingwell, K. Hand, D. Kelton, K. Leslie, Y. Schukken, and S. Godden. 2011a. Diagnosing intramammary infections: Comparison of multiple versus single quarter milk samples for the identification of intramammary infections in lactating dairy cows. J. Dairy Sci. 94:5515-5522.

Dohoo, I. R., W. Martin, and H. Stryhn. 2010. Veterinary Epidemiologic Research. 2nd ed. VER Inc., Charlottetown, Prince Edward Island, Canada.

Dohoo, I. R., J. Smith, S. Andersen, D. F. Kelton, and S. Godden. 2011b. Diagnosing intramammary infections: Evaluation of definitions based on a single milk sample. J. Dairy Sci. 94:250-261.

Dürr, J. W., R. I. Cue, H. G. Monardes, J. Moro-Méndez, and K. M. Wade. 2008. Milk losses associated with somatic cell counts per breed, parity and stage of lactation in Canadian dairy cattle. Livest. Sci. 117:225-232.

Emanuelson, U., T. Olsson, T. Mattila, G. Astrom, and O. Holmberg 1988. Effects of parity and stage of lactation on adenosine triphosphate, somatic cell count and antitrypsin content in cows' milk. J. Dairy Res. 55:49-55.

Emanuelson, U., P. A. Oltenacu, and Y. T. Grohn. 1993. Nonlinear mixed model analyses of five production disorders of dairy cattle. J. Dairy Sci. 76:2765-2772.

Emerson, P. M., and J. H. Wilkinson. 1965. Urea and oxalate inhibition of the serum lactate dehydrogenase. J. Clin. Pathol. 18:803-807.

Forsback, L., H. Lindmark-Mansson, A. Andren, M. Akerstedt, and K. Svennersten-Sjaunja. 2009. Udder quarter milk composition at different levels of somatic cell count in cow composite milk. Animal 3:710-717.

Godden, S. M., K. D. Lissemore, D. F. Kelton, K. E. Leslie, J. S. Walton, and J. H. Lumsden. 2001. Factors associated with milk urea concentrations in Ontario dairy cows. J. Dairy Sci. 84:107-114.

Grabowski, N. T. 2000. Körpergewichtsentwicklung, Milchinhaltsstoffe und Milchmengenleistung als Kriterien zur laktationsbegleitenden Beurteilung des Gesundheitszustandes hochleistender DSB-Kühe 
in Laufstallhaltung. Vol. DVM. Tierärztliche Hochschule, Hannover, Germany.

Green, L. E., Y. H. Schukken, and M. J. Green. 2006. On distinguishing cause and consequence: Do high somatic cell counts lead to lower milk yield or does high milk yield lead to lower somatic cell count? Prev. Vet. Med. 76:74-89.

Hagnestam, C., U. Emanuelson, and B. Berglund. 2007. Yield losses associated with clinical mastitis occurring in different weeks of lactation. J. Dairy Sci. 90:2260-2270.

Halasa, T., K. Huijps, O. Østerås, and H. Hogeveen. 2007. Economic effects of bovine mastitis and mastitis management: A review. Vet. Q. 29:18-31.

Harmon, R. J. 1994. Physiology of mastitis and factors affecting somatic cell counts. J. Dairy Sci. 77:2103-2112.

Jaartsveld, F. H. J., E. van Puffelen, J. Oskam, M. J. M. Tielen, M. W. A. Verstegen, and G. A. A. Albers. 1983. Somatic cell counts in milk of dairy cows in relation to stage of lactation, age, production level and presence of pathogens. Neth. Milk Dairy J. 37:79-90.

Kitchen, B. J. 1981. Review of the progress of dairy science: Bovine mastitis: Milk compositional changes and related diagnostic tests. J. Dairy Res. 48:167-188.

Kitchen, B. J., G. Middleton, and M. Salmon. 1978. Bovine milk Nacetyl-beta-D-glucosaminidase and its significance in the detection of abnormal udder secretions. J. Dairy Res. 45:15-20.

Laevens, H., H. Deluyker, Y. H. Schukken, L. De Meulemeester, R. Vandermeersch, E. De Muelenaere, and A. de Kruif. 1997. Influence of parity and stage of lactation on the somatic cell count in bacteriologically negative dairy cows. J. Dairy Sci. 80:3219-3226.

Larsen, T. 2005. Determination of lactate dehydrogenase (LDH) activity in milk by a fluorometric assay. J. Dairy Res. 72:209-216.

Larsen, T., C. M. Rontved, K. L. Ingvartsen, L. Vels, and M. Bjerring. 2010. Enzyme activity and acute phase proteins in milk utilized as indicators of acute clinical E. coli LPS-induced mastitis. Animal 4:1672-1679.

Lindmark-Månsson, H., U. Svensson, M. Paulsson, G. Aldén, B. Frank, and G. Johnsson. 2000. Influence of milk components, somatic cells and supplemental zinc on milk processability. Int. Dairy J. 10:423-433.

Mattila, T., J. Syvajarvi, and M. Sandholm. 1986. Milk antitrypsin, NAGase, plasmin and bacterial replication rate in whey. Effects of lactation stage, parity and daily milk yield. Zentralbl. Veterinarmed. B. 33:462-470.

Natzke, R. P., R. W. Everett, and D. S. Postle. 1972. Normal milk somatic cell counts. J. Milk Food Technol. 35:261-263.

Nielsen, N. I., T. Larsen, M. Bjerring, and K. L. Ingvartsen. 2005. Quarter health, milking interval, and sampling time during milking affect the concentration of milk constituents. J. Dairy Sci. $88: 3186-3200$.

Nilsson, L. 1994. Studies on diagnosis of mastitis according to a new method-MASTISTRIP. Pages 1:104, 102:135-137 in Proc. 18th Nordic Vet. Congr., Reykjavik, Iceland.

Nilsson, L., P. Jonsson, A. Franklin, and O. Holmberg. 1990. The use of Selma and MASTISTRIP as diagnostic tools in mastitis therapy. Page 150 in Proc. Int. Conf. Mastitis: Physiol. Pathol.? Nat. Satellite BST Symp., Ghent, Belgium.

Nyman, A. K., U. Emanuelson, A. H. Gustafsson, and W. K. Persson. 2009. Management practices associated with udder health of firstparity dairy cows in early lactation. Prev. Vet. Med. 88:138-149.
Nyman, A. K., U. Emanuelson, K. Holtenius, K. L. Ingvartsen, T. Larsen, and K. P. Waller. 2008. Metabolites and immune variables associated with somatic cell counts of primiparous dairy cows. J. Dairy Sci. 91:2996-3009.

Oltner, R., M. Emanuelson, and H. Wiktorsson. 1985. Urea concentrations in milk in relation to milk yield, live weight, lactation number and amount and composition of feed given to dairy cows. Livest. Prod. Sci. 12:47-57.

Oltner, R., and H. Wiktorsson. 1983. Urea concentrations in milk and blood as influenced by feeding varying amounts of protein and energy to dairy cows. Livest. Prod. Sci. 10:457-467.

Persson, Y., A. K. Nyman, and U. Gronlund-Andersson. 2011. Etiology and antimicrobial susceptibility of udder pathogens from cases of subclinical mastitis in dairy cows in Sweden. Acta Vet. Scand. $53: 36$.

Piccinini, R., E. Binda, M. Belotti, V. Dapra, and A. Zecconi. 2007. Evaluation of milk components during whole lactation in healthy quarters. J. Dairy Res. 74:226-232.

Reksen, O., L. Solverod, and O. Osteras. 2008. Relationships between milk culture results and composite milk somatic cell counts in Norwegian dairy cattle. J. Dairy Sci. 91:3102-3113.

Roseler, D. K., J. D. Ferguson, C. J. Sniffen, and J. Herrema. 1993 Dietary protein degradability effects on plasma and milk urea nitrogen and milk nonprotein nitrogen in Holstein cows. J. Dairy Sci. $76: 525-534$.

Sandholm, M., T. Honkanen-Buzalski, L. Kaartinen, and S. Pyörälä. 1995. The Bovine Udder and Mastitis. M. Sandholm, T. Honkanen-Buzalski, L. Kaartinen, and S. Pyörälä, ed. Gummerus Kirjapaino Oy, Jyväskylä, Finland.

Schepers, A. J., T. J. Lam, Y. H. Schukken, J. B. Wilmink, and W. J. Hanekamp. 1997. Estimation of variance components for somatic cell counts to determine thresholds for uninfected quarters. J. Dairy Sci. 80:1833-1840.

Sundekilde, U. K., N. A. Poulsen, L. B. Larsen, and H. C. Bertram. 2013. Nuclear magnetic resonance metabonomics reveals strong association between milk metabolites and somatic cell count in bovine milk. J. Dairy Sci. 96:290-299.

Svensson, C., A. K. Nyman, W. K. Persson, and U. Emanuelson. 2006. Effects of housing, management, and health of dairy heifers on first-lactation udder health in southwest Sweden. J. Dairy Sci. 89:1990-1999.

Syrstad, O., and I. Røn. 1979. Variation in somatic cell counts of milk samples from individual cows. Acta Vet. Scand. 20:555-561.

Vecht, U., H. J. Wisselink, and P. R. Defize. 1989. Duth national mastitis survey. The effect of herd and animal factors on somatic cell count. Neth. Milk Dairy J. 43:425-435.

Walsh, S., F. Buckley, D. P. Berry, M. Rath, K. Pierce, N. Byrne, and P. Dillon. 2007. Effects of breed, feeding system, and parity on udder health and milking characteristics. J. Dairy Sci. 90:5767-5779.

Wenz, J. R., L. K. Fox, F. J. Muller, M. Rinaldi, R. Zeng, and D. D. Bannerman. 2010. Factors associated with concentrations of select cytokine and acute phase proteins in dairy cows with naturally occurring clinical mastitis. J. Dairy Sci. 93:2458-2470. 